\title{
Ulnar and Humeral Heads Forming Separate Bellies. A Rare Case of Digastric Flexor Carpi Ulnaris Muscle
}

\author{
Cabezas Ulnar y Humeral Formando Vientres Separados. \\ Un Caso Raro del Músculo Flexor Ulnar del Carpo Digástrico
}

Mohandas Rao K. G.; Seetharama M. Bhat; Venkataramana V. \& Vincent Rodrigues

RAO, K. G. M.; BHAT, S. M.; Venkataramana, V. \& RODRIGUES, V. Ulnar and humeral heads forming separate bellies. A rare case of digastric flexor carpi ulnaris. Int. J. Morphol., 27(1):31-34, 2009.

SUMMARY: Proper knowledge of muscular variations is essential for both anatomists and surgeons. Variations of the flexor carpi ulnaris (FCU) are not very common. We are reporting an unusual case of FCU muscle with two bellies. The two heads (ulnar and humeral) of the muscle continued as two separate bellies and the tendons of which joined each other slightly proximal to the wrist before getting inserted to pisiform bone. Further, detailed literature review of variations of FCU muscle is done and the developmental basis for the variation and its surgical importance are discussed.

KEY WORDS: Flexor carpi ulnaris muscle; Variations of forearm muscles; Ulnar head; Humeral head.

\section{INTRODUCTION}

Variations in muscles of the extensor compartment of the fore arm are quite common. However, in the flexor compartment not many variations are noted. There are very few reports of the variations of flexor carpi ulnaris muscle (FCU). Normally FCU arises by two heads namely humeral and ulnar. The smaller humeral head arises from the medial epicondyle of the humerus and larger ulnar head has an extensive origin from the medial margin of the olecranon process, proximal two thirds of posterior border of ulna, an aponeurosis which is common for FCU, extensor carpi ulnaris muscle and flexor digitorum profundus muscle and intermuscular septum between it and flexor digitorum superficialis muscle. The two heads of origin are connected with each other by a tendinous arch (Standring et al., 2005). We are reporting a rare case where the two heads of the FCU muscle formed two separate bellies.

\section{CASE REPORT}

During routine dissections for the first-year medical students of Melaka Manipal Medical College, Manipal, we observed a case where FCU showed two bellies arising separately. The limb belonged to the left side of an approximately 60 -year-old male cadaver.

Two bellies of the muscles were seen on the medial part of the front of the forearm one by the side of the other. The belly on the medial aspect was larger and was arising from the medial margin of the olecranon process, proximal two thirds of posterior border of ulna, an aponeurosis which is common for FCU, extensor carpi ulnarismuscle and flexor digitorum profundus muscle and intermuscular septum between it and flexor digitorum superficialis muscle. The belly on the lateral side was smaller and was taking its origin from the medial humeral epicondyle along with the other superficial forearm flexors (Figure 1). Based on their origin, the bellies were identified as ulnar and humeral bellies respectively. Both the bellies were supplied by separate branches of ulnar nerve close to their origin (Figure 2). The two bellies remained separately throughout and continued with their tendons in the distal part of the forearm.

Belly of the ulnar head was unipinnate and its tendon started some where in the middle of the forearm on the lateral aspect of the belly. It then passed distally medial to the tendon of the humeral head, slightly proximal to the wrist; it 
was joined by the latter to form a common tendon, which ended by getting inserted to pisiform bone (Fig. 1).

The humeral head had relatively smaller belly and was bipinnate in nature. Its tendon began at almost same level as that of ulnar head, passed distally on the lateral aspect of the tendon of the ulnar head and slightly proximal to the wrist the two tendons joined together to form a common tendon which ended in the pisiform bone (Fig. 1).

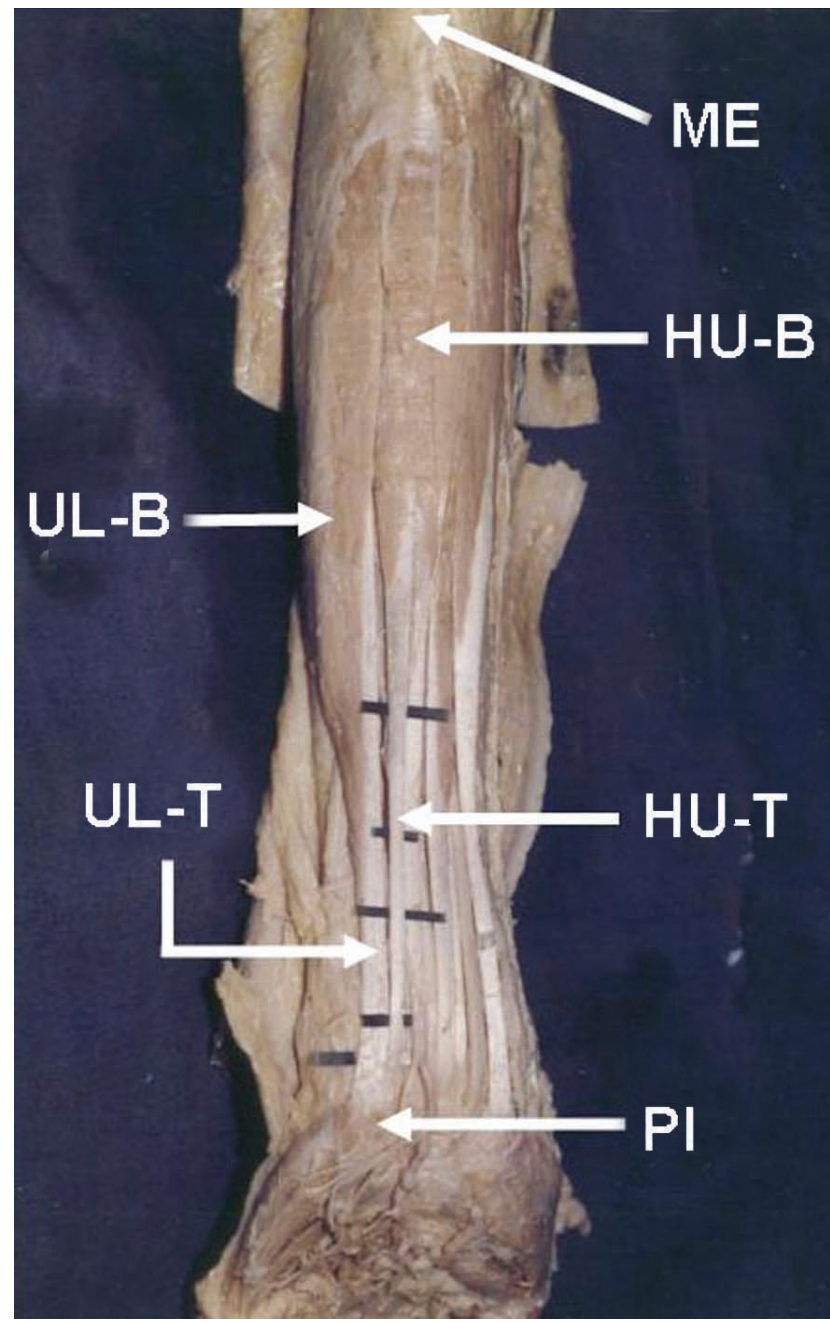

Fig. 1. Photograph of dissected anterior compartment of the forearm showing the 2 heads of flexor carpi ulnaris forming two separate bellies (UL-B: ulnar belly, HU-B: humeral belly). The tendons of the two bellies (UL- T and HU-T) join each other and get inserted to the pisiform bone (PI). Also seen is medial epicondyle (ME) from which the fibers of humeral head arise.

\section{DISCUSSION}

Not many variations of FCU are reported in the literature. Grechenig et al. (2000) have conducted an

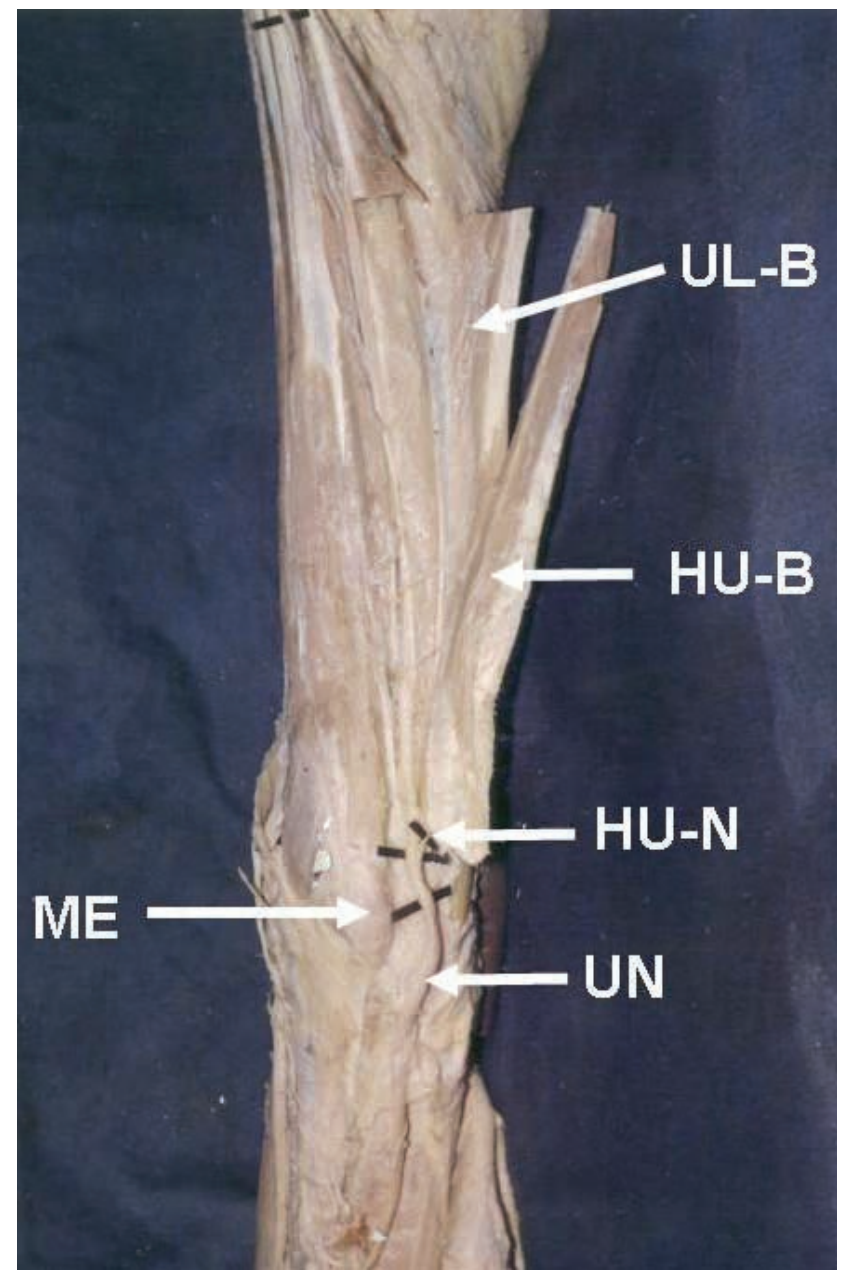

Fig. 2. Photograph of dissected anterior compartment of the forearm where ulnar (UL-B) and humeral (HU-B) bellies of flexor carpi ulnaris are cut and reflected to expose the ulnar nerve (UN) and its branch (HU-N) to the humeral belly as it is passing behind the medial epicondyle (ME).

exclusive study on this muscle to evaluate the anatomical variations of the musculotendinous junction and the variations of its insertion onto the pisiform. They have reported three typical anatomical variations of FCU 1) a large muscle belly running distally almost to the insertion onto the pisiform; 2) the muscle belly ending more proximally, with some large fibres running parallel to the tendon and almost reaching the pisiform; 3) the musculotendinous junction ending more proximally, with only single fibres continuing distally. Another case of variation of FCU was reported by al-Qattan \& Duerksen (1992). They have reported a case of duplication of the tendon of FCU with splitting of the ulnar nerve. The ulnar slip of the tendon was inserted into the pisiform bone and the radial slip into the proximal phalanx of the ring finger. Lopez Milena et al. (2001) have observed an anomalous 
accessory muscle, distal and deep to flexor carpi ulnaris muscle, which was responsible for a soft tissue mass over forearm causing symptoms associated with ulnar compression. Pribyl \& Moneim (1994) have reported a case where an anomalous muscle originated on the flexor carpi ulnaris muscle, it was innervated by ulnar nerve, and it joined the flexor digiti minimi muscle distally. In one of the cases reported by Zook et al. (1988), a segment of the ulnar nerve composing approximately $15 \%$ of its volume separated from the main trunk of the ulnar nerve, perforated the flexor carpi ulnaris tendon, and then rejoined the ulnar nerve. A case similar to the lateral belly of the present case was reported by Arnold \& Zech (1977), where, an accessory muscle of the forearm originated from the medial epicondyle and the fascia of the forearm and inserted into the pisiform bone and retinaculum. However, this muscle was observed in addition to a normal FCU. From above review of literature it is evident that, formation of separate bellies and then tendons from the two heads of origin of FCU muscle is being reported for the first time.

The limb muscles are developed from myogenic mesodermal cells derived from the somites. They migrate from the somites at approximately the fourth week. These cells coalesce into two common muscle masses, one ventral and one dorsal, which then split to fashion the definitive muscles. Every muscle is identifiable by 7 weeks. The muscles are differentiated from superficial to deep. FCU is one of the first few muscles to split off. Initially it shows two muscular elements which later unite to form one muscle. Occurrence of two separate bellies of the muscle reported in this case may be because of the failure of fusion of the two muscular elements. However, tendons develop independently and are derived from limb bud mesoderm rather than from somites. A study by Lim et al. (1999) has showed that based on intramuscular innervation and vascular supply, FCU can be divided into humeral and an ulnar compartments, each with its own primary nerve branch. A similar report was given by Segal et al. (2002) where they reported that, the nerve to the flexor carpi ulnaris clearly innervates two architectural partitions within the muscle. The innervation pattern to the flexor carpi ulnaris muscle is mathcing with muscle fiber architecture characteristics indicating consistent anatomical partitioning within the muscle. These studies also support the development of FCU from two developmental elements.

FCU is one of the main flexors at the wrist and its humeral head has been proved to play a major role in maintaining a sustained antigravity tension that prevents the wrist from buckling during standing (Glenn \& Whitney, 1987). It is also the main muscle overlying the medial collateral ligament of elbow joint and plays a major role in its support (Davidson et al., 1995). In addition, many clinical and surgical significance of this muscle are reported. The detailed architectural properties of the human FCU and its implications for tendon transfer surgery were studied by Friden et al. (2004). They have suggested that, when used in tendon transfer, the properly mobilized FCU has a much greater excursion. In patients suffering from radial nerve palsy, tendon transfer of the FCU to the extensor carpi radialis longus and extensor digitorum communis muscles is commonly done (Lieber \& Friden, 1997; Lieber et al., 1996). In patients suffering from late ulnar nerve paralysis, compression of ulnar nerve by muscular arcade of FCU is released by opening it longitudinally (Mansat et al., 1983). The FCU is recommended to be the primary structure for measuring the tissue pressure as well as for surgical decompression. (Frober \& Linss, 1994)

From the above literature review it is quite evident that FCU is an important muscle clinically and surgically. Its variations are not very common. It is very essential not only for the anatomists but also for the clinicians and surgeons to be aware of the probable variations of this muscle for the proper diagnosis and planning of operative treatment. Further, these muscles can be useful in surgical rehabilitation of patients with paralytic disorders and also for tendon grafting. To conclude, we would like to state that, the observations made by us in the present case will supplement our knowledge of variations of this muscle, which should be quite useful in forearm and hand surgery.

RAO, K. G. M.; BHAT, S. M.; VENKATARAMANA, V. \& RODRIGUES, V. Cabeza ulnar y humeral formando vientres separados. Un caso raro del músculo flexor ulnar del carpo digástrico. Int. J. Morphol., 27(1):31-34, 2008.

RESUMEN: El correcto conocimiento de las variaciones musculares es esencial para anatomistas y cirujanos. Variaciones del músculo flexor ulnar del carpo (MFUC) no son muy comunes. Se reporta un caso inusual del MFUC con dos vientres. Las dos cabezas (ulnar y húmeral) del músculo continuaron como dos vientres separados. Los tendones se unieron entre sí, ligeramente proximal a la muñeca, antes de llegar a su inserción en el hueso pisiforme. Se hace una detallada revisión de la literatura de las variaciones del MFUC y son discutidas las bases del desarrollo de las variaciones, destacándose además su importancia quirúrgica. humeral.

PALABRAS CLAVE: Músculo flexor ulnar del carpo; Variaciones de los músculos del antebrazo; Cabeza ulnar; Cabeza 


\section{REFERENCES}

al-Qattan, M. M. \& Duerksen, F. A variant of flexor carpi ulnaris causing ulnar nerve compression. J. Anat., 180(1):189-90, 1992.

Arnold, G. \& Zech, M. An accessory muscle and additional variants of the forearm. Handchirurgie., 9(3):135-6, 1977.

Davidson, P. A.; Pink, M.; Perry, J. \& Jobe, F. W. Functional anatomy of the flexor pronator muscle group in relation to the medial collateral ligament of the elbow. Am. J. Sports Med., 23(2):245-50, 1995.

Friden, J.; Lovering, R. M. \& Lieber, R. L. Fiber length variability within the flexor carpi ulnaris and flexor carpi radialis muscles: implications for surgical tendon transfer. J. Hand Surg., 29(5):909-14, 2004.

Frober, R. \& Linss, W. Anatomic bases of the forearm compartment syndrome. Surg. Radiol. Anat., 16(4):3417, 1994.

Glenn, L. L. \& Whitney, J. F. Contraction properties and motor nucleus morphology of the two heads of the cat flexor carpi ulnaris muscle. J. Morphol., 191(1):17-23, 1987.

Grechenig, W.; Clement, H.; Egner, S.; Tesch, N. P.; Weiglein, A. \& Peicha, G. Musculo-tendinous junction of the flexor carpi ulnaris muscle. An anatomical study. Surg. Radiol. Anat., 22(5-6):255-60, 2000.

Lieber, R. L. \& Friden, J. Intraoperative measurement and biomechanical modeling of the flexor carpi ulnaris-toextensor carpi radialis longus tendon transfer. J. Biomech. Eng., 119(4):386-91, 1997.

Lieber, R. L.; Ponten, E.; Burkholder, T. J. \& Friden J. Sarcomere length changes after flexor carpi ulnaris to extensor digitorum communis tendon transfer. J. Hand Surg., 21(4):612-8, 1996.

Lim, A. Y.; Kumar, V. P.; Hua, J.; Pereira, B. P. \& Pho, R. W. The neuromuscular compartments of the flexor carpi ulnaris. Plast. Reconstr. Surg., 103(3):1046-51, 1999.

Lopez Milena, G.; Ruiz Santiago, F.; Chamorro Santos, C. \& Canadillas Barea, L. Forearm soft tissue mass caused by an accessory muscle. Eur. Radiol., 11(8):1487-9, 2001.
Mansat, M.; Bonnevialle, P.; Fine, X.; Guiraud, B. \& Testut, M. F. Late ulnar paralysis. Study of seventeen cases. Ann. Chir. Main., 2(2):116-24, 1983.

Pribyl, C. R. \& Moneim, M. S. Anomalous hand muscle found in the Guyon's canal at exploration for ulnar artery thrombosis. A case report. Clin. Orthop. Relat. Res., 306:120-3, 1994.

Segal, R. L.; Catlin, P. A.; Krauss, E. W.; Merick, K. A. \& Robilotto, J. B. Anatomical partitioning of three human forearm muscles. Cells TissuesOrgans, 170(2-3):183-97, 2002.

Standring, S.; Harold E.; Jeremiah Healy, C.; Johnson, D.; Williams, A. \& Collins, A. Gray's Anatomy: The Anatomical Basis of Clinical Practice. $39^{\text {th }}$ Edition. New York, Elsevier/ Churchill Livingstone, 2005. p.877.

Zook, E. G.; Kucan, J. O. \& Guy, R. J. Palmar wrist pain caused by ulnar nerve entrapment in the flexor carpi ulnaris tendon. J. Hand Surg., 13(5):732-5, 1988.

Correspondence to:

Dr. Mohandas Rao K. G.,

Assistant professor,

Department of Anatomy,

Melaka Manipal Medical College (Manipal Campus),

International Centre for Health Sciences,

Manipal-576104,

Karnataka State - INDIA

Phone: 91-820- 2922570, 2922519

Fax: 91-820-2571905

Email: mohandaskg@gmail.com

Received: 02-09-2007

Accepted: 28-06-2008 